\title{
【奨励賞研究】
}

\section{空心偏平型経皮電力伝送トランスの正確な効率測定 一測定法による比較一}

\author{
加我 正 \\ 東京理科大学大学院 基礎工学研究科 電子応用工学専攻
}

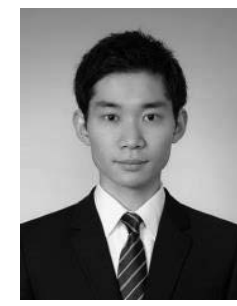

\section{1. 緒言}

現在, 補助人工心臓 (Ventricular Assist Device:VAD) 一, 体外 から電力を供給するための有線による感染症が問題になっている. そこで, 平らな 2 枚の円形コイルを用い, 電磁誘導作用により体 内一非接触で電力伝送する空心偏平型経皮電力伝送システム (Transcutaneous Energy Transmission System: TETS) が研究され ている. 従来までに電力伝送効率の向上を目的として, 理論効率 と実測効率の比較検討を行った結果, 共振周波数 $1 \mathrm{MHz}$ 付近に おいて実測効率と理論効率が一致しないことが明らかとなった. そこで, 本研究では実測効率において測定装置の帯域幅, サン プリングレート, さらにコモンモード電流に焦点を当て原因解明を 行ってきた ${ }^{1)}$. さらには, オシロスコープに加えて, ネットワークア ナライザも用いて実測効率を測定し, 理論効率との比較検討を行 った.

\section{2. 理論効率}

TETS の等価回路を Fig. 1 に示した. 1, 2 次キャパシタ $C_{1}$, $C_{2}$ はコイル間の電力伝送効率を向上させるための $L C$ 直列共 振用キャパシタであり，1，2 次自己インダクタンス $L_{1}, L_{2}$ と それぞれ共振を取った。 $\omega$ は角周波数， $R \mathrm{~L}$ はVAD を模擬し た負荷抵抗， $r_{\mathrm{C} 1}, r_{\mathrm{C} 2}$ は 1,2 次キャパシタの損失抵抗， $r_{\mathrm{L} 1}$, $r_{\mathrm{L} 2}$ は 1,2 次コイルの損失抵抗である.これらの值を LCR メ ータ（HIOKI, IM3536）により測定し, 共振周波数及び共振 周波数以外の理論効率式 ${ }^{2)}$ 上り，本研究の共振周波数である $989.8 \mathrm{kHz}$ 付近の正確な理論効率を算出した. 相互インダクタ ンス $M$ はノイマンの公式より求めた.

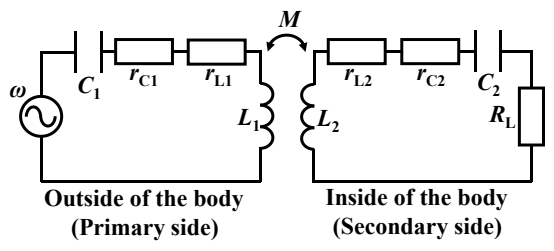

Fig. 1 Equivalent circuit of TETS.

\section{3. 実測効率}

本研究で用いたオシロスコープ (Agilent, DSO-X4054A / DSO-X2002A), ネットワークアナライザ(Keysight, E5063A, 以下 NA) は 500MHz 帯域であった. オシロスコープを用いて効率を正 しく測定するため, 測定に次のような工夫を行った. 測定回路図 を Fig. 2 に示しす. コモンモード電流を抑制するために 1 次 側のアンプ出力部にコモンモードフィルタとして, $1 \mathrm{MHz}$ の 減衰率が-52 dB のコモンモードチョークコイルを挿入した. また 2 次側のオシロスコープはバッテリである無停電電源装 置（UPS）を用いグラウンドに接続しない状態で測定を行っ た. オシロスコープを用いた場合の実測効率は 1 次側電力 $P_{1}$ 及 び 2 次側の負荷抵抗 $R_{\mathrm{L}}$ にかかる電力 $P_{2}$ を測定し求めた.

NA を用いた測定は, コモンモードチョーク等は入れず, 単純 に S パラメータを測定し, 実測効率を求めた. 2 種類の測定装置 を用いて共振周波数 $989.8 \mathrm{kHz}$ と共振周波数以外の周波数であ
る 500-1250 kHz の電力伝送効率を測定した.

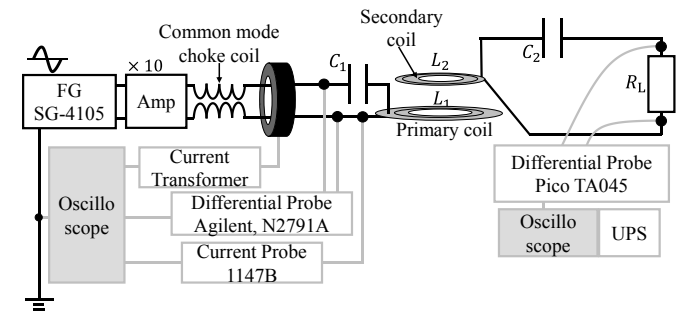

Fig. 2 Measurement circuit.

\section{4. 結果及び考察}

$989.8 \mathrm{kHz}$ と $500-1250 \mathrm{kHz}$ の理論効率とオシロスコープ, NA による実測効率の比較を Fig. 3 (a)，（b）に示した. Fig. 3 (a), (b)の $989.8 \mathrm{kHz}$ 及び 500-700 kHz における理論効率と実測効 率の差は, オシロスコープで, $2.02 \%$ 及び 6.79-33.6\%, NA で 1.51\%及び 6.20-16.2 \%であった. オシロスコープ法の誤差が大き い原因として, NA は測定対象物までのキャリブレーションが可能 であるのに対し, オシロスコープではできないことが考えられる. ま た, 電流プローブの測定誤差も考えられる. 従って, オシロスコー プでは, 周波数によって等価回路にプローブの容量分や誤差な どを加えた理論効率を算出する必要があると考えられる. また, 共 振周波数 $989.8 \mathrm{kHz}$ において, コモンモード電流は以前のコモン モードチョークや UPS を入れていないときと入れている時とで, 10.3〜17.7\%程減少させることに成功した.

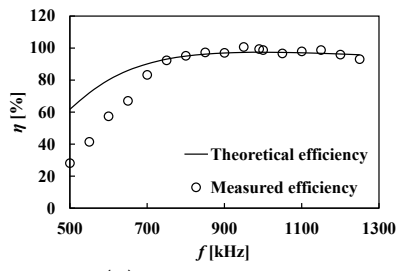

(a) Oscilloscope

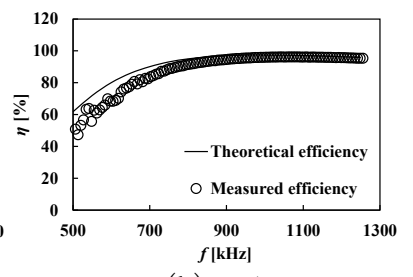

(b) NA
Fig. 3 Comparison of theoretical and measured efficiency.

\section{5. 結言}

オシロスコープ, NA を用いた理論効率と実測効率とを比較し た結果, NA を用いた方がより正確であった. しかしながらオシロ スコープ法でも, $700 \mathrm{kHz}$ よりも高い周波数においては理論効率 $\pm 3.4 \%$ 範囲で正確な効率測定が可能であった. いずれの方法 も測定法として有用であることが明らかとなった。

\section{参考文献}

1) 柴建次, 吉川秀一, 小谷野純一, 体内埋込型人工心臓用経 皮エネルギー伝送システムー液体浸漬時における伝送効率 と温度上昇の実測一. 日本 $A E M$ 学会誌, 2015; Vol. 23, No. $1:$ pp. $179-186$.

2) 萩原述史, 電磁結合による非接触電力伝送の原理について. 電気学会論文誌. D, 2011; Vol. 131, No. 5:pp. 708-713. 